\title{
Hyperfunction of CD4 CD25 regulatory $T$ cells in de novo acute myeloid leukemia
}

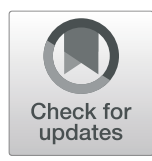

\author{
Yuling Wan, Congxiao Zhang, Yingxi Xu, Min Wang, Qing Rao, Haiyan Xing, Zheng Tian, Kejing Tang, \\ Yingchang Mi, Ying Wang ${ }^{*}$ (D) and Jianxiang Wang ${ }^{*}$
}

\begin{abstract}
Background: Acute myeloid leukemia (AML) is a common hematopoietic malignancy that has a high relapse rate, and the number of regulatory T cells (Tregs) in AML patients is significantly increased. The aim of this study was to clarify the role of Tregs in the immune escape of acute myeloid leukemia.

Methods: The frequencies of Tregs and the expression of PD-1, CXCR4 and CXCR7 were examined by flow cytometry. The expression of CTLA-4 and GITR was tested by MFI. Chemotaxis assays were performed to evaluate Treg migration. The concentrations of SDF-1 $\mathrm{a}, \mathrm{IFN}-\gamma$ and TNF-a were examined by ELISA. Coculture and crisscrosS coculture experiments were performed to examine Treg proliferation and apoptosis and the effect of regulatory $B$ cells (Breg) conversion.

Results: The frequencies of Tregs in peripheral blood and bone marrow in AML patients were increased compared with those in healthy participants. AML Tregs had robust migration towards bone marrow due to increased expression of CXCR4. AML Treg-mediated immunosuppression of T cells was achieved through proliferation inhibition, apoptosis promotion and suppression of IFN- $\gamma$ production in $\mathrm{CD}^{+} \mathrm{CD} 25^{-} \mathrm{T}$ cells. AML Bregs induced the conversion of $\mathrm{CD}^{+} \mathrm{CD} 25^{-} \mathrm{T}$ cells to Tregs.

Conclusion: In AML patients, the Breg conversion effect and robust CXCR4-induced migration led to Treg enrichment in bone marrow. AML Tregs downregulated the function of $\mathrm{CD}^{+} \mathrm{CD} 25^{-} \mathrm{T}$ cells, contributing to immune escape.
\end{abstract}

Keywords: Regulatory T cells, Regulatory B cells, Acute myeloid leukemia, Tumor immunity, Immune escape

\section{Background}

Regulatory $\mathrm{T}$ cells (Tregs), which were originally identified as $\mathrm{CD} 4{ }^{+} \mathrm{CD} 25^{+} \mathrm{T}$ cells, are critical for maintaining immunological self-tolerance in healthy individuals by actively suppressing self-reactive lymphocytes [1]. However, in tumor immunity, Tregs are considered pivotal regulators of immune escape, as they suppress the proliferation and function of immune cells through cell-tocell contact and inhibitory cytokine production [2].

\footnotetext{
* Correspondence: wangying1@ihcams.ac.cn; wangjx@ihcams.ac.cn

State Key Laboratory of Experimental Hematology, National Clinical Research Center for Blood Diseases, Institute of Hematology \& Blood Diseases Hospital, Chinese Academy of Medical Sciences \& Peking Union Medical College, No. 288, Nanjing Road, Tianjin 300020, China
}

Previous studies demonstrated that Tregs are increased in many solid tumors [3-6], as well as hematopoietic malignancies [7-9]. In addition, an increased Treg frequency is related to poor prognosis $[6,10,11]$.

Acute myeloid leukemia (AML) is a hematopoietic malignancy driven by a sequence of somatic mutations in multipotential primitive cells or progenitor cells. Currently, although most AML patients achieve complete remission (CR) after induction chemotherapy, approximately $60 \%$ of patients who receive subsequent consolidation chemotherapy still cannot achieve long survival. As immunotherapy is a promising new therapeutic option for hematologic malignancies [12], Tregs can be a

(c) The Author(s). 2020 Open Access This article is licensed under a Creative Commons Attribution 4.0 International License, which permits use, sharing, adaptation, distribution and reproduction in any medium or format, as long as you give appropriate credit to the original author(s) and the source, provide a link to the Creative Commons licence, and indicate if changes were made. The images or other third party material in this article are included in the article's Creative Commons licence, unless indicated otherwise in a credit line to the material. If material is not included in the article's Creative Commons licence and your intended use is not permitted by statutory regulation or exceeds the permitted use, you will need to obtain permission directly from the copyright holder. To view a copy of this licence, visit http://creativecommons.org/licenses/by/4.0/ The Creative Commons Public Domain Dedication waiver (http://creativecommons.org/publicdomain/zero/1.0/) applies to the data made available in this article, unless otherwise stated in a credit line to the data. 
novel target. However, little is known regarding the role of Tregs in the immune escape of AML and the possible upstream mechanisms.

As cell-to-cell contact plays an essential role in the immunosuppression of Tregs [13], the accumulation of Tregs in bone marrow (BM) is crucial for AML progression. A previous study indicated that stromal cellderived factor (SDF)- $1 \alpha /$ chemokine (C-X-C motif) receptor (CXCR) 4 signaling plays an important role in regulating Treg levels in $\mathrm{BM}$ and peripheral blood (PB) [14]. Blockade of the SDF- $1 \alpha / C X C R 4$ axis alone, which is crucial for Treg migration, reduces ovarian tumor growth and peritoneal dissemination and selectively reduces intratumoral Tregs [15]. Therefore, we hypothesize that excessive chemotaxis of Tregs from PB to $\mathrm{BM}$ is the reason for Treg enrichment. In addition, regulatory B cells (Bregs) are another negative regulator that supports immunological tolerance by producing interleukin-10 (IL-10), IL-35, and transforming growth factor $\beta$ (TGF- $\beta$ ), as well as influencing the expansion of $\mathrm{T}$ cells [16]. Olkhanud et al. indicated that tumorevoked Bregs promoted breast cancer metastasis by converting $\mathrm{CD}^{+} \mathrm{T}$ cells into Tregs using a mouse $4 \mathrm{~T} 1$ breast cancer model [17]. Accordingly, Bregs may play a similar role in inducing Treg conversion in AML immune escape.

To provide an in-depth understanding of Tregs in AML, in the present study, we investigated the proliferation, cytokine production and migration capacity of Tregs in newly diagnosed untreated AML patients.

\section{Methods}

\section{Cell samples}

EDTA anticoagulated bone marrow aspirates and peripheral blood samples were collected from 45 (24 male and 21 female) de novo AML patients with a median age of 36 years (range, 18-68 years) and 29 healthy donors (17 male and 12 female; age range, 21-56 years) from the Institute of Hematology \& Blood Diseases Hospital of the Chinese Academy of Medical Sciences from March 2015 to April 2017.

\section{Antibodies and other agents}

Manufacturer names are included in supplementary materials.

\section{Cell isolation and flow cytometry}

Mononuclear cells from BM and PB were isolated by density gradient centrifugation (Ficoll, TBDscience). EDTA was used as an anticoagulant.

For surface markers, cells were stained with monoclonal PD1-APC/Cy7, CTLA4-PE, GITR-PE, CXCR4-PE or CXCR7-PE antibodies simultaneously with CD4-FITC, CD25-Pacific Blue and CD127-APC antibodies.
For intracellular FOXP3 expression, cells were fixed and permeabilized with FOXP3 fixation/permeabilization solution (Ebioscience) after staining with CD4-FITC, CD25-Pacific Blue and CD127-APC and were then stained with FOXP3-PE antibody.

For intracellular cytokine expression, cells were measured after stimulation with phorbol myristate acetate (PMA, $0.05 \mu \mathrm{g} / \mathrm{ml}$; Sigma-Aldrich) and ionomycin $(1 \mu \mathrm{g} /$ $\mathrm{ml}$, Sigma-Aldrich) in the presence of brefeldin A (BFA $0.01 \mu \mathrm{g} / \mathrm{ml}$, BD Biosciences) at $37^{\circ} \mathrm{C}$ for $5 \mathrm{~h}$. After staining with CD19-FITC, CD24-PE and CD38-APC antibodies, the cells were fixed and permeabilized, followed by intracellular staining with IL-10-PE/Cy7 and TGF- $\beta$ PerCP/Cy5.5 antibodies according to the manufacturer's instructions.

The concentration of antibodies was determined as recommended by the manufacturer. Isotype controls were used to set correct gating for both extracellular and intracellular markers. Gating strategies are presented in the supplementary materials. Data acquisition was performed on a Canto II flow cytometer (BD Biosciences) and analyzed by FlowJo software (Version 7.6; TreeStar).

\section{Purification of lymphocyte subpopulations}

Three $\mathrm{T}$ cell subpopulations, including $\mathrm{CD} 4^{+} \mathrm{CD} 25^{-} \mathrm{T}$ cells, $\mathrm{CD} 8^{+} \mathrm{T}$ cells, and $\mathrm{CD} 4^{+} \mathrm{CD} 25^{+}$Tregs, were purified using a commercial CD3-positive selection magnetic activated cell sorting (MACS) isolation kit (Miltenyi Biotec), a CD8-positive selection isolation kit (Miltenyi Biotec) and a $\mathrm{CD} 44^{+} \mathrm{CD} 25^{+}$human Treg isolation kit (Miltenyi Biotec) according to the manufacturer's instructions. To verify the phenotype of Tregs, some sorted $\mathrm{CD} 4{ }^{+} \mathrm{CD} 25^{+}$Tregs were stained with CD4-FITC, CD25-Pacific Blue and CD127-APC antibodies and analyzed on a Canto II flow cytometer (BD Biosciences). Flow cytometry results showed that the purity of $\mathrm{CD} 4{ }^{+} \mathrm{CD} 25^{+} \mathrm{CD} 127^{\text {low } /-}$ Tregs was $>95 \%$. For $\mathrm{CD} 19^{+} \mathrm{CD} 24^{+}$Breg isolation, BM mononuclear cells were stained with CD19-FITC and CD24-PE antibodies and sorted on an Aria III flow cytometer (BD Biosciences) according to the manufacturer's instructions, and the purity of isolated Bregs was > 95\%.

\section{Chemotaxis assay}

Purified PB Tregs were subjected to a migratory assay with SDF-1 or BM fluid as chemotactic media. Purified PB Tregs $\left(1 \times 10^{5}\right.$ cells/well $)$ were induced to migrate towards either SDF-1 (100 ng/mL; R\&D Systems) or BM fluid diluted in RPMI 1640 with 10\% fetal bovine serum (FBS) in a 24-well plate containing 5 - $\mu \mathrm{m}$ pore polycarbonate filters (Costar Corporation). After incubation at $37^{\circ} \mathrm{C}$ for $3 \mathrm{~h}$, migrating cells were harvested from the lower compartment. The harvested cells were enumerated using a hemocytometer. The percentage of 
migrating cells was calculated by determining the ratio of the number of cells harvested from the lower compartment to the total number of cells loaded in the upper compartment. CXCR4 neutralization experiments were performed by incubating the cells with AMD3100 (100 ng/mL; Sigma-Aldrich) for $30 \mathrm{~min}$ before adding the cells to the top chamber.

\section{Proliferation assays for T cells}

To assess the proliferation of $\mathrm{T}$ cells, freshly purified $\mathrm{CD} 4^{+} \mathrm{CD} 25^{-} \mathrm{T}$ cells or $\mathrm{CD} 8^{+} \mathrm{T}$ cells were stained with 5 $\mathrm{mmol} / \mathrm{L}$ carboxyfluorescein succinimidyl ester (CFSE) (Invitrogen) according to the manufacturer's instructions. The stained cells were then cultured in a 24-well plate alone or with Tregs at a ratio of $4: 1$ at $37^{\circ} \mathrm{C}$ with $5 \% \mathrm{CO}_{2}$ in X-VIVO ${ }^{\mathrm{rm}} 15$ medium (Lonza) supplemented with 5\% FBS and recombinant interleukin-2 (100 units/ $\mathrm{ml}$; R\&D systems) and stimulated with anti-CD3/CD28 beads (Miltenyi Biotec) at a ratio of 1:1. After 5 days, proliferating $\mathrm{CD} 4^{+} \mathrm{CD} 25^{-} \mathrm{T}$ cells or $\mathrm{CD} 8^{+} \mathrm{T}$ cells were identified as CFSE-diluted subsets. The control group consisted of $\mathrm{CD}^{+} \mathrm{CD} 25^{-} \mathrm{T}$ cells that were not cocultured with Tregs but were stained with CFSE.

\section{Apoptosis assays for T cells}

To assess the apoptosis of $\mathrm{T}$ cells, freshly purified CD $4^{+} \mathrm{CD} 25^{-} \mathrm{T}$ cells or $\mathrm{CD}^{+} \mathrm{T}$ cells were cultured in a 24-well plate alone or with Tregs at a ratio of 4:1 at $37{ }^{\circ} \mathrm{C}$ with $5 \% \mathrm{CO}_{2}$ in $\mathrm{X}-\mathrm{VIVO}^{\mathrm{rm}} 15$ medium (Lonza) supplemented with 5\% FBS and recombinant Interleukin-2 (100 units/ml; R\&D Systems) and were stimulated with anti-CD3/CD28 beads (Miltenyi Biotec). After 3 days, apoptotic $\mathrm{CD}^{+} \mathrm{CD}^{-} 5^{-} \mathrm{T}$ cells or $\mathrm{CD}^{+} \mathrm{T}$ cells were assayed by an Annexin v/PI apoptosis kit (BD Biosciences) according to the manufacturer's instructions.

\section{Detection of IFN- $\gamma$, TNF- $\alpha$ and SDF-1 levels}

Culture supernatants obtained from the apoptosis assays were analyzed for IFN- $\gamma$ and TNF- $\alpha$ by ELISA (Pepro Tech). SDF-1 was also detected in BM fluid and serum by ELISA (Pepro Tech). The detection range of all three kits was $0-10 \mathrm{ng} / \mathrm{ml}$ according to the manufacturer's instructions.

\section{Conversion of $\mathrm{CD}^{+} \mathrm{CD} 25^{-} \mathrm{T}$ cells to $\mathrm{CD} 4^{+} \mathrm{CD} 25^{+} \mathrm{Foxp}^{+}$ Tregs}

To assess the efficiency of Breg-mediated conversion of Tregs, freshly purified $\mathrm{CD} 4^{+} \mathrm{CD} 25^{-} \mathrm{T}$ cells were cultured in a 24-well plate alone or with Bregs at a ratio of $1: 1$ at $37{ }^{\circ} \mathrm{C}$ with $5 \% \mathrm{CO}_{2}$ in X-VIVO ${ }^{\mathrm{rm}} 15$ medium (Lonza) supplemented with 5\% FBS and recombinant Interleukin-2 (100 units/ml; R\&D Systems) and were stimulated with anti-CD3/CD28 beads (Miltenyi Biotec). After 5 days, the cells were analyzed for the expression of CD4, CD25 and Foxp3 on a Canto II flow cytometer (BD Biosciences).

\section{Statistical analysis}

The data are shown as the mean \pm SEM or median (P25, P75). The data were tested for normality, assuming the test result was $P>0.10$. Statistical significance of differences between groups was determined by Student's $t$ tests. Nonnormally distributed data were analyzed by the Mann-Whitney $U$ test. A value of $P<0.05$ was determined to be statistically significant. Analyses were carried out with SPSS 16.0 software (SPSS Science).

\section{Results}

Increased frequencies of Tregs in AML patients

We used $\mathrm{CD} 4{ }^{+} \mathrm{CD} 25^{+} \mathrm{CD} 127^{\text {low/- }}$ as the immunophenotype of Tregs and verified this subgroup by FoxP3 expression. Flow cytometry analysis showed that $\mathrm{CD} 4{ }^{+} \mathrm{CD} 25^{+} \mathrm{CD} 127^{\text {low/- }} \mathrm{T}$ cells and $\mathrm{CD} 4^{+} \mathrm{CD} 25^{+} \mathrm{Foxp}^{+}$ $\mathrm{T}$ cells belonged to the same group (Fig. 1). Compared with those of healthy participants, the frequencies of $\mathrm{CD} 4{ }^{+} \mathrm{CD} 25^{+} \mathrm{CD} 127^{\text {low/- }}$ Tregs in the BM of AML patients were significantly increased $(3.60 \%$ [range: 2.00 to $5.20 \%$ ] vs $1.50 \%$ [range: 1.10 to $2.13 \%$ ], $P=0.0062$ ), as were $\mathrm{CD}^{+} \mathrm{CD}^{2} 5^{+}$Foxp $^{+}$Tregs $(2.70 \%$ [range: 0.90 to $3.70 \%$ ] vs $1.00 \%$ [range: 0.68 to $1.65 \%$ ], $P=0.0239$ ) (Fig. 2a-b). However, the expression of programmed cell death 1 (PD-1) on the surface of Tregs in AML patients was not significantly different from that in healthy participants $(P>0.05)$ (Fig. 2c). Tregs with cytotoxic T lymphocyte-associated protein 4 (CTLA4) and glucocorticoid-induced tumor necrosis factor receptor (GITR) were undetectable in the analyzed samples.

\section{Enhanced migratory capacity of Tregs due to increased expression of CXCR4}

The ability of Tregs to suppress immune cells through contact-dependent mechanisms depends on their migratory capacity to the primary target tissue [18]. Therefore, excessive migration of Tregs to the BM could be the reason for Treg enrichment in the BM of AML patients. As SDF-1 $\alpha / C X C R 4$ is crucial for Treg migration to BM and an alternate SDF- $1 \alpha$ receptor, CXCR7, still needs to be investigated [14, 19], we first designed a chemotaxis assay to exclude the effect of other soluble chemoattractants in BM fluid from AML patients on Treg migration. SDF-1 $\alpha$, BM fluid from healthy participants and BM fluid from AML patients were used individually as chemotactic media. The results showed that PB Tregs from AML patients had stronger migration to all three media than normal Tregs (SDF-1 $\alpha$ : $27.69 \pm 1.84 \%$ vs. $11.73 \pm 0.27 \%, P=0.0010$; normal BM: $12.20 \pm 0.55 \%$ vs. $7.37 \pm 0.75 \%, \quad P=0.0007 ; \quad$ AML BM: $13.73 \pm 0.47 \%$ vs. $7.67 \pm 0.67 \%, \quad P=0.0018$, respectively). Moreover, the 

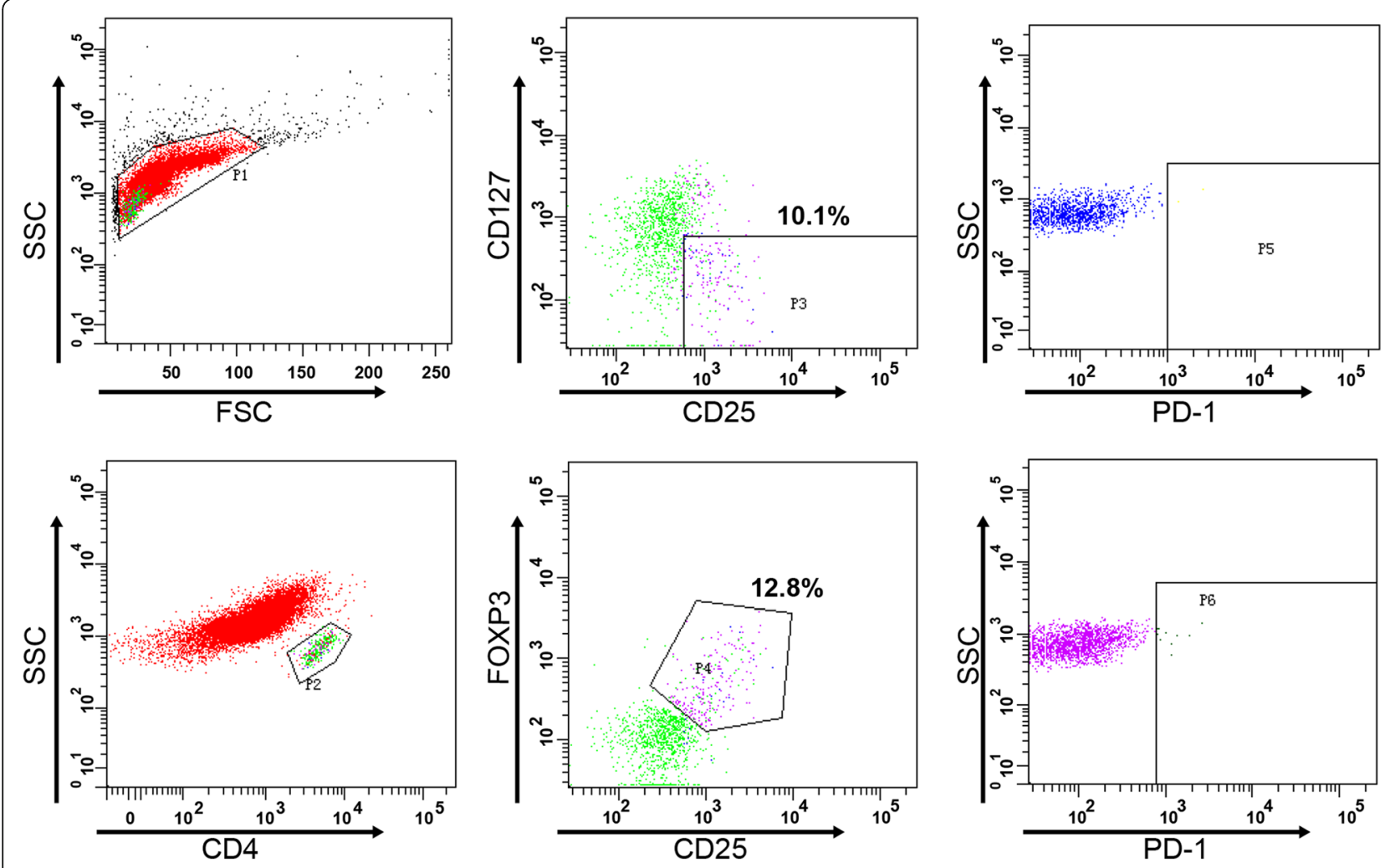

Fig. 1 Flow cytometry analysis of $\mathrm{CD} 4^{+} \mathrm{CD} 25^{+} \mathrm{CD} 127^{\text {low/- }}$ and $\mathrm{CD} 4^{+} \mathrm{CD} 25^{+} \mathrm{Foxp} 3^{+}$Tregs in BM from newly diagnosed AML patients

same PB Tregs showed similar migratory capacities to normal BM fluid and AML BM fluid. After adding the CXCR4 blocker, the migration of PB Tregs from AML patients and controls was significantly decreased, with no significant differences $(P>0.05)$ (Fig. 3a-d).

The levels of SDF- $1 \alpha$ in BM fluid from patients and controls were similar $(1844 \pm 300.2 \mathrm{ng} / \mathrm{mL}$ vs. $1374 \pm 134.8 \mathrm{ng} /$ $\mathrm{mL}, P=0.1380$ ) (Fig. 3e). In addition, BM fluid from AML patients had increased levels of SDF-1 compared with that of serum $(1844 \pm 300.2 \mathrm{ng} / \mathrm{mL}$ vs. $1123 \pm 168.9 \mathrm{ng} / \mathrm{mL}, P=$
0.0494) (Fig. 3f). To further investigate the factors influencing the migration of PB Tregs, flow cytometry was performed to detect the expression of CXCR4 and CXCR7 on Tregs. The results showed that the expression of CXCR4 on AML Tregs was significantly higher than that of the controls (44.15\% [range: 19.78 to $71.78 \%$ ] vs $5.20 \%$ [range: 3.10 to $25.75 \%$ ], $P=0.0190$ ), while the expression of CXCR7 showed no significant differences between the two groups (3.40\% [range: 2.10 to $4.10 \%$ ] vs $2.50 \%$ [range; 1.88 to $4.85 \%], P=0.8861$ ) (Fig. 3g-h).






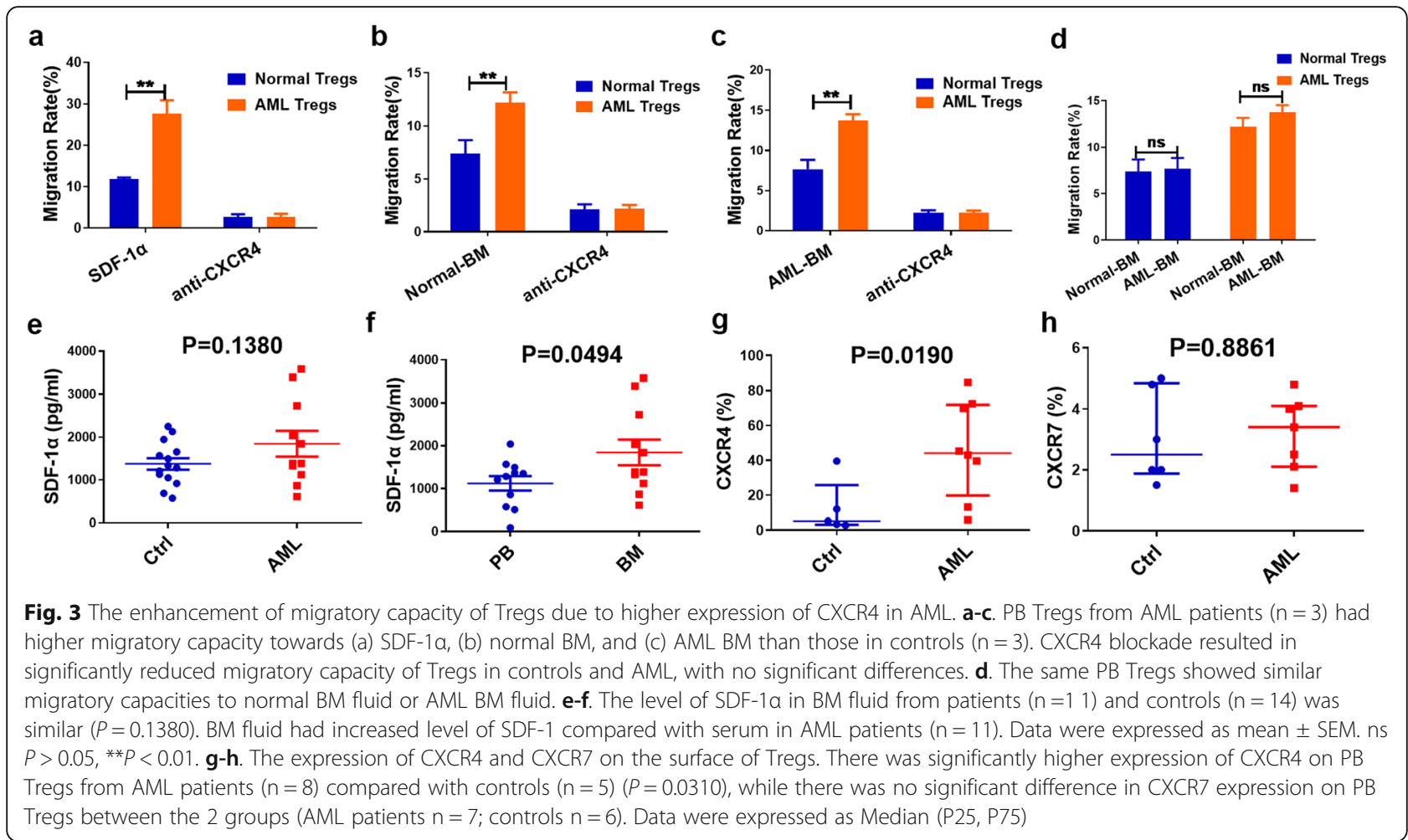

\section{AML Treg-mediated immunosuppression of immune T cells}

To study the immunosuppressive effects of Tregs on $\mathrm{T}$ cells, coculture and crisscross coculture experiments of Tregs with $\mathrm{CD} 4^{+} \mathrm{CD} 25^{-} \mathrm{T}$ cells were performed. The results showed that Tregs from controls or AML patients promoted the apoptosis of normal $\mathrm{CD} 4^{+} \mathrm{CD} 25^{-} \mathrm{T}$ cells compared with that of $\mathrm{CD} 4{ }^{+} \mathrm{CD} 25^{-} \mathrm{T}$ cells cultured alone $(17.03 \pm 1.97 \%$ vs. $34.40 \pm 2.10 \%, P=0.0038 ; 17.03 \pm 1.97 \%$ vs. $55.27 \pm 3.47 \%, P=0.007)$. A similar trend was also found in $\mathrm{AML} \mathrm{CD}^{+} \mathrm{CD} 25^{-} \mathrm{T}$ cells $(20.40 \pm 1.69 \%$ vs. $32.47 \pm 2.83 \%, P=0.0215 ; 20.40 \pm 1.69 \%$ vs. $68.93 \pm 2.10 \%$, $P<0.0001$, respectively). Compared with normal Tregs, AML Tregs significantly promoted the apoptosis of both normal and AML CD4 ${ }^{+} \mathrm{CD} 25^{-} \mathrm{T}$ cells $(34.40 \pm 2.10 \%$ vs. $55.27 \pm 3.47 \%, P=0.0068 ; 32.47 \pm 2.83 \%$ vs. $68.93 \pm 2.10 \%$, $P=0.0005$, respectively). In particular, AML Tregs had the most significant proapoptotic effect on AML CD4 $4^{+} \mathrm{CD} 25^{-}$ $\mathrm{T}$ cells (Fig. 4a). Tregs also promoted the apoptosis of $\mathrm{CD}^{+} \mathrm{T}$ cells $(P<0.05)$. There were no significant differences when separately comparing the different stages of apoptosis (Supplemental Figure 4A-D). However, the proapoptotic effect on $\mathrm{CD}^{+} \mathrm{T}$ cells seemed less different between normal and AML Tregs $(P>0.05)$ (Fig. 4b).

In addition, Tregs from AML patients inhibited the proliferation of both normal CD4 ${ }^{+} \mathrm{CD} 25^{-} \mathrm{T}$ cells (proliferation of $\mathrm{CD}^{+} \mathrm{CD} 25^{-} \mathrm{T}$ cells decreased from 91.8 to $50.1 \%$ ) and $\mathrm{AML} \mathrm{CD}^{+} \mathrm{CD} 25^{-} \mathrm{T}$ cells (proliferation of $\mathrm{CD}^{+}{ }^{+} \mathrm{CD} 25^{-} \mathrm{T}$ cells decreased from 86.2 to $42.1 \%$ ) compared with that of Tregs in the controls (Fig. 4c). However, no proliferation inhibition was observed for $\mathrm{CD}^{+} \mathrm{T}$ cells (proliferation of $\mathrm{CD}^{+} \mathrm{T}$ cells was approximately 90\%) (Fig. 4d).

Interferon- $\gamma$ (IFN- $\gamma)$ is an important Th1-type cytokine [20]. Coculture supernatants obtained from the apoptosis assays were analyzed for IFN- $\gamma$, and the data revealed that Tregs from AML patients suppressed the secretion of IFN- $\gamma$ by both normal and AML CD $4^{+} \mathrm{CD} 25^{-} \mathrm{T}$ cells $(P=0.0065$ and $P=0.0004$, respectively), especially for autologous $\mathrm{CD} 4{ }^{+} \mathrm{CD} 25^{-} \mathrm{T}$ cells (the level of IFN- $\gamma$ decreased from baseline value of $635.0 \pm 24.7 \mathrm{pg} / \mathrm{ml}$ to $170.5 \pm 35.3 \mathrm{pg} / \mathrm{ml}$ ) (Fig. $4 \mathrm{e}$ ). The same trend was observed for $\mathrm{CD}^{+} \mathrm{T}$ cells, but the differences were not statistically significant. In contrast, an inhibitory effect was not observed for the cytokine tumor necrosis factor $\alpha$ (TNF- $\alpha)(P>0.05)$ (Fig. 4f).

\section{AML Breg-induced conversion of $\mathrm{CD} 4^{+} \mathrm{CD} 25^{-} \mathrm{T}$ cells to CD4 ${ }^{+} \mathrm{CD} 25^{+}$Foxp $^{+}$Tregs}

Previous studies confirmed that in breast cancer, tumorinduced Bregs promote tumor metastasis by converting dormant $\mathrm{CD} 44^{+} \mathrm{CD} 25^{-} \mathrm{T}$ cells into $\mathrm{CD} 44^{+} \mathrm{CD} 25^{+} \mathrm{Foxp}^{+}$ Tregs, while in the absence of tumor-induced Bregs, the conversion of Tregs was significantly reduced and tumor metastasis was blocked [17]. To further address the role of Bregs in the conversion of Tregs, we first detected the frequencies of $\mathrm{CD} 19^{+} \mathrm{CD} 24^{\text {high }} \mathrm{CD} 38^{\text {high }}$ Bregs in $\mathrm{BM}$ 

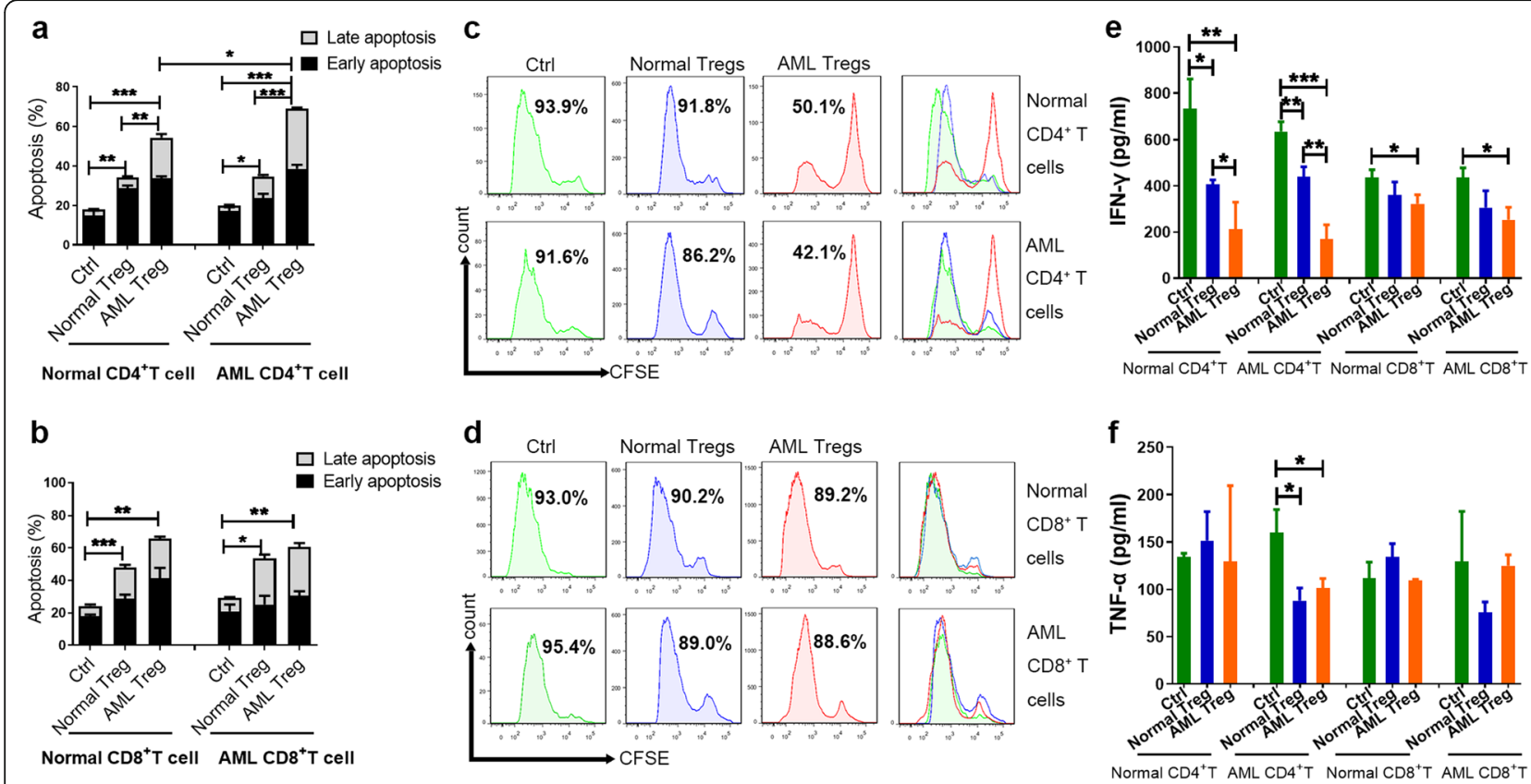

Fig. 4 AML Treg-mediated immunosuppression for immune T cells. a. Both normal Tregs $(n=3)$ and AML Tregs $(n=3)$ resulted in increased apoptosis of T cells compared with $C D 4^{+} C D 25^{-}$T cells cultured alone, particularly AML Tregs. b. Compared with normal Tregs $(n=3)$, AML Tregs $(n=3)$ had the same trend of progression of $C D 8^{+} T$ cells, however the differences remained not statistically significant $(P>0.05)$. C. AML Tregs inhibited the proliferation of $C D 4^{+} C D 25^{-} T$ cells (AML patients $n=3$; controls $n=3$ ). $\mathbf{d}$. AML Tregs could not inhibit the proliferation of $C D 8^{+} T$ cells (AML patients $n=3$; controls $n=3$ ). e. The levels of IFN- $\gamma$ showed that T cells from both normal controls and AML patients cocultured with AML Tregs had significantly lower levels of IFN- $\gamma$ production than those of controls. CD $8^{+} T$ cells showed the same trend, but the differences were not statistically significant. (AML patients $n=7$; controls $n=6$ ). $\mathbf{f}$. The inhibitory effect was not observed for TNF-a $(P>0.05)$. (AML patients $n=7$; controls $n=6$ ). Data were expressed as mean \pm SEM. ${ }^{*} P<0.05$, ${ }^{*} P<0.01,{ }^{*}{ }^{*} P<0.001$

from newly diagnosed AML patients by flow cytometry (Fig. 5a). The percentage of $\mathrm{CD} 19^{+} \mathrm{CD} 24^{\text {high }} \mathrm{CD} 38^{\text {high }}$ Bregs in $\mathrm{BM} \mathrm{CD} 19^{+} \mathrm{B}$ cells from AML patients was significantly increased compared with those from healthy participants (7.50\% [range: 5.20 to $12.65 \%$ ] vs $4.80 \%$ [range: 2.05 to $6.95 \%$ ], $P=0.0255$ ) (Fig. 5b). We also detected intracellular cytokine expression, such as IL-10 and TGF- $\beta$, in Bregs from AML patients or healthy controls and found no significant differences between the two groups $(P>0.05)$ (Fig. 5c). Therefore, we considered whether this conversion was achieved through cell-tocell contact by Bregs in AML patients. We cocultured Bregs with $\mathrm{CD} 4{ }^{+} \mathrm{CD} 25^{-} \mathrm{T}$ cells for 5 days in vitro, analyzed the expression of CD4, CD25 and Foxp3 by flow cytometry and found that normal Bregs cannot convert $\mathrm{CD} 4^{+} \mathrm{CD} 25^{-} \mathrm{T}$ cells into $\mathrm{CD} 4^{+} \mathrm{CD} 25^{+} \mathrm{Foxp}^{+}$Tregs. Interestingly, the conversion of $\mathrm{CD} 4^{+} \mathrm{CD} 25^{-} \mathrm{T}$ cells to $\mathrm{CD}^{+}{ }^{+} \mathrm{CD} 25^{+} \mathrm{Foxp}^{+}$Tregs was significantly increased when normal or AML CD4 $4^{+} \mathrm{CD} 25^{-} \mathrm{T}$ cells were cocultured with AML Bregs $(2.31 \pm 0.27 \%$ vs. $7.53 \pm 0.65 \%$, $P=0.0018 ; 1.89 \pm 0.32 \%$ vs. $12.77 \pm 1.63 \%, P=0.0028)$. The conversion effect was most significant for autologous $\mathrm{CD} 4{ }^{+} \mathrm{CD} 25^{-} \mathrm{T}$ cells (Treg ratio increased from baseline value of $1.67 \pm 0.34 \%$ to $12.77 \pm 1.63 \%$ ) (Fig. $5 \mathrm{~d}$ ).

\section{Discussion}

AML accounts for more than $25 \%$ of adult leukemia cases [21]. In addition to the well-known cytogenetic and molecular genetic abnormalities in the pathogenesis of AML, immune escape also plays a significant role. Tregs are considered pivotal regulators of immune escape. As Tregs suppress the proliferation and function of immune cells through cell-to-cell contact [13], the enrichment of Tregs in tumor sites is crucial. In addition, using CD25-specific monoclonal antibodies to deplete Tregs in a variety of different mouse strains promoted the rejection of murine tumor cell lines, including melanoma and leukemia [22-24]. Previous studies have shown that compared to the frequencies in healthy individuals, the frequencies of Tregs in both $\mathrm{PB}$ and $\mathrm{BM}$ of AML patients are increased $[25,26]$. Nevertheless, little is known about the mechanism of Tregs in the immune escape of AML.

FoxP3 is critical and specific for Treg identification. However, as FoxP3 is expressed intracellularly, and cells to be fixed and ruptured during staining, FoxP3 cannot be used to separate human Tregs for functional studies or in vivo expansion. In addition, CD127 is downregulated in Tregs and is negatively correlated with Foxp3 expression 


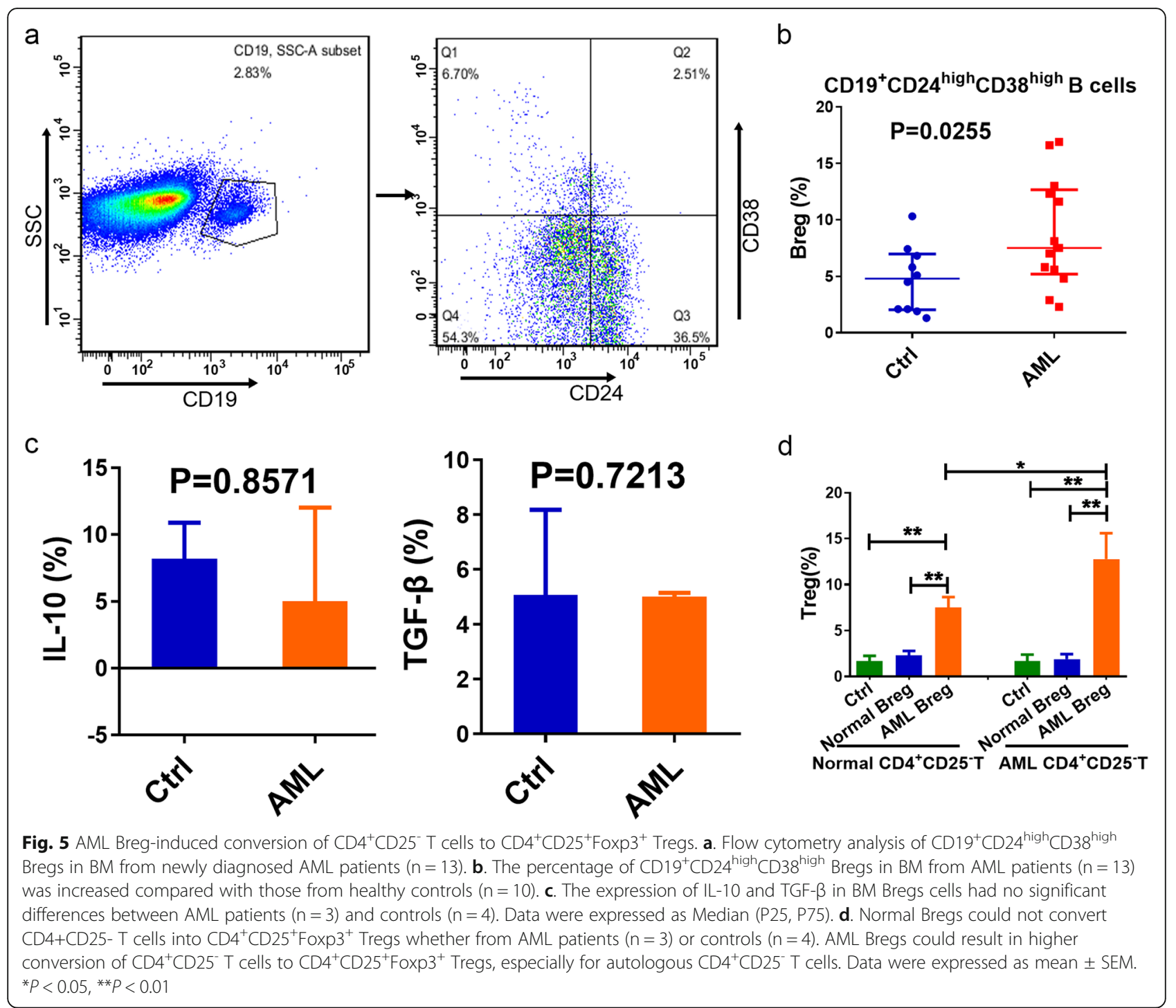

[27]. Therefore, we used $\mathrm{CD} 4^{+} \mathrm{CD} 25^{+} \mathrm{CD} 127^{\text {low/- }}$ cells as the immunophenotype of Tregs and found that the frequencies of $\mathrm{CD} 4^{+} \mathrm{CD} 25^{+} \mathrm{CD} 127^{\text {low/- }}$ Tregs in $\mathrm{BM}$ and $\mathrm{PB}$ were increased in AML patients. We deduced that excessive chemotaxis of Tregs from $\mathrm{PB}$ to $\mathrm{BM}$ is the reason for this enrichment. The homing of Tregs from $\mathrm{PB}$ to $\mathrm{BM}$, which is the target tissue in AML, is crucial for their immunosuppressive function via direct contact with immune cells. The SDF- $1 \alpha / C X C R 4$ signaling pathway is critical for Treg trafficking from PB to BM [14]. Moreover, the mechanism of CXCR7, another receptor of SDF- $1 \alpha$, still needs further investigation [19]. Our study demonstrated that the enrichment of Tregs in AML patients was due to excessive migration caused by increased expression of CXCR4 rather than abnormal expression of CXCR7 on Tregs or abnormal secretion of SDF- $1 \alpha$ by the hematopoietic microenvironment.
Checkpoint inhibition was taken into consideration as contributing to the immunosuppressive effect of Tregs in AML. A series of inhibitory membrane proteins on the surface of Tregs can exert their immunosuppressive function through cell-to-cell contact [28]. However, in our experiments, differences in the expression of PD-1 on the surface of Tregs [10, 29], were not significantly different between AML and healthy participants, which was consistent with several solid cancers [30-32]. Therefore, we inferred that the immunosuppressive function of Tregs in AML patients does not rely on the overexpression of PD-1.

In addition, to further investigate the effects of Tregs on other immune cells, we designed in vitro coculture and crisscross coculture experiments. Our study revealed that compared to normal Tregs, AML Tregs were more capable of inhibiting proliferation, promoting apoptosis and 
suppressing the production of IFN- $\gamma$ in both normal and AML CD $4^{+} \mathrm{CD} 25^{-} \mathrm{T}$ cells. In particular, Tregs from AML patients had the most significant effect on autologous $\mathrm{CD} 4{ }^{+} \mathrm{CD} 25^{-} \mathrm{T}$ cells. Interestingly, the inhibitory effect on $\mathrm{CD}^{+}{ }^{+} \mathrm{T}$ cells was not significantly different from that of controls. Although IFN- $\gamma$ production by $\mathrm{CD}^{+} \mathrm{T}$ cells showed a similar decreasing trend, the difference was not obvious enough $(P>0.05)$. In ovarian cancer, a decreased ratio of $\mathrm{CD}^{+} \mathrm{T}$ cells to Tregs in tumors is related to poor prognosis, indicating suppression of effector $\mathrm{CD} 8^{+} \mathrm{T}$ cells by Tregs [1]. The effect of Tregs on $\mathrm{CD}^{+} \mathrm{T}$ cells in AML could be due to other mechanisms than cell-to-cell contact. Inhibitory cytokines such as TGF- $\beta$ suppress $\mathrm{CD} 8^{+} \mathrm{T}$ cell proliferation [33], and cytokines could be the manner by which Tregs influence $\mathrm{CD}^{+} \mathrm{T}$ cells. In addition, as the function of $\mathrm{CD}^{+} \mathrm{T}$ cells relies on the help from $\mathrm{CD} 4^{+} \mathrm{T}$ cells, the immunosuppressive effect could be indirect via $\mathrm{CD} 4^{+} \mathrm{CD} 25^{-} \mathrm{T}$ cells. Crisscross coculture experiments further ruled out the possibility that $\mathrm{T}$ cells had decreased resistance to Tregs. Therefore, we suggest that in AML, Treg-mediated immunosuppression of $\mathrm{CD} 4^{+} \mathrm{CD} 25^{-} \mathrm{T}$ cells increases, leading to reduced proliferation, increased apoptosis and impaired secretion of IFN- $\gamma$; instead, the resistance of immune $\mathrm{T}$ cells to Tregs decreases, which eventually causes immune escape of AML cells.

The in-depth study of AML Tregs raised the question of the possible upstream factors in the initiation of AML Treg abnormalities. Mizoguchi et al. [34]. found a B cell subgroup that secreted IL-10 and inhibited the progression of inflammatory bowel disease, formally suggesting the concept of Bregs. Bregs are involved in the development of various diseases, including autoimmune diseases, infections and tumors. These cells are involved in the regulation of graft-versus-host disease (GVHD), mainly through the secretion of IL-10, TGF- $\beta$ and other cytokines [35], regulation of $\mathrm{T}$ cells, amplification of Tregs [36-38] and other means of participating in immune regulation. A study showed that the number of Bregs in the PB of liver cancer patients was higher than that in healthy individuals [39]. Olkhanud et al. discovered that Bregs could convert dormant $\mathrm{CD} 4^{+} \mathrm{CD} 25^{-} \mathrm{T}$ cells into $\mathrm{CD} 44^{+} \mathrm{CD} 25^{+}$Foxp $3^{+}$Tregs in breast cancer [17]. In our study, the percentage of $\mathrm{CD} 19^{+} \mathrm{CD} 24^{\text {high }} \mathrm{CD} 38^{\text {high }}$ Bregs in $\mathrm{BM}$ was significantly increased. A coculture experiment proved that AMLinduced Bregs robustly converted $\mathrm{CD} 4^{+} \mathrm{CD} 25^{-} \mathrm{T}$ cells to $\mathrm{CD} 4^{+} \mathrm{CD} 25^{+} \mathrm{Foxp}^{+}{ }^{+}$Tregs, while normal Bregs did not. However, as secretion of IL-10 and TGF- $\beta$ did not show obvious differences between AML and normal Bregs, we deduced that IL-10 and TGF- $\beta$ were not the reason for the conversion. Little research has been conducted on the impact of Bregs on Tregs. In breast cancer, PD- $1^{+}$ Bregs increase the conversion [40]. Although that study did not use PD-1 ${ }^{-}$Bregs or anti-PD-1 antibodies for comparison, checkpoint inhibitors are still a good entry point for Breg investigations. The conversion effect was most significant when AML Bregs were cocultured with AML CD $4^{+} \mathrm{CD} 25^{-} \mathrm{T}$ cells. Therefore, tumor-induced $\mathrm{CD} 4{ }^{+} \mathrm{CD} 25^{-} \mathrm{T}$ cells were more prone to conversion.

\section{Conclusion}

In AML bone marrow, the frequencies of Bregs increase and induce the conversion of $\mathrm{CD} 4^{+} \mathrm{CD} 25^{-} \mathrm{T}$ cells to $\mathrm{CD} 4^{+} \mathrm{CD} 25^{+} \mathrm{Foxp}^{+}$Tregs. On the other hand, more PB Tregs home to the BM, which also causes the enrichment of Tregs in the BM. Treg-mediated immunosuppression in immune cells increases, leading to reduced proliferation and increased apoptosis and secretion of IFN- $\gamma$, especially for $\mathrm{CD} 4^{+} \mathrm{CD} 25^{-} \mathrm{T}$ cells.

\section{Supplementary information}

Supplementary information accompanies this paper at https://doi.org/10. 1186/s12885-020-06961-8.

Additional file 1: Manufacturer names of agents.

Additional file 2: Supplemental figures.

Additional file 3: Diagnostic information of participants.

\section{Abbreviations}

AML: Acute myeloid leukemia; Tregs: Regulatory T cells; Bregs: Regulatory B cells; CR: Complete remission; BM: Bone marrow; SDF-1a: Stromal cell-derived factor 1a; CXCR4: Chemokine (C-X-C motif) receptor 4; PB: Peripheral blood; IL-10: Interleukin-10; TGF- $\beta$ : Transforming growth factor $\beta$; PMA: Phorbol myristate acetate; BFA: Brefeldin A; MACS: Magnetic activated cell sorting; FBS: Fetal bovine serum; CFSE: Carboxyfluorescein succinimidyl ester; PD1: Programmed cell death protein-1; CTLA4: Cytotoxic T-lymphocyteassociated protein 4; GITR: Glucocorticoid-induced TNFR family-related protein; IFN- $\gamma$ : Interferon- $\gamma$; TNF-a: Tumor necrosis factor a; GVHD: Graftversus-host disease; HLA: Human leukocyte antigen; TCR: T cell receptor

\section{Acknowledgements}

Not applicable.

\section{Authors' contributions}

YW and JW designed the study, YLW and YX performed the research, YLW, CZ, YX, MW, QR, HX, ZT, KT, YM, YW and JW analysed the data. YLW, CZ and $Y W$ wrote the manuscript. All authors have read and approved the manuscript.

\section{Funding}

This work was financially supported by National Natural Science Foundation (Grant no. 81400136), National Natural Science Foundation (Grant no. 81670159), National Natural Science Foundation of China (81830005), CAMS Innovation Fund for Medical Sciences (Grant no. CIFMS 2016-12M-3-004, CIFMS 2016-12M-1-001), The National Key Research and Development Program for Precision Medicine (Grant no. 2017YFC0909800). The funds mentioned were used for reagents and consumable materials purchasing and language editing of the manuscript. The funders had no role in study design, data collection and analysis or decision to publish of the manuscript.

\section{Availability of data and materials}

All data generated or analyzed during the present study are included in this published article. The authors declare that materials described in the manuscript, including all relevant raw data, will be freely available to any scientist wishing to use them for non-commercial purposes, without breaching participant confidentiality. 


\section{Ethics approval and consent to participate}

The protocol of the present study, involving human clinical samples, was approved by the Ethics Committee of Chinese Academy of Medical Sciences Institute of Hematology and Blood Diseases Hospital. Written informed consent was obtained from all patients.

\section{Consent for publication}

Not applicable.

\section{Competing interests}

The authors declare that they have no competing interests.

\section{Received: 5 December 2019 Accepted: 13 May 2020}

\section{Published online: 26 May 2020}

\section{References}

1. Takeuchi $Y$, Nishikawa $\mathrm{H}$. Roles of regulatory T cells in cancer immunity. Int Immunol. 2016;28(8):401-9.

2. Facciabene A, Motz GT, Coukos G. T-regulatory cells: key players in tumor immune escape and angiogenesis. Cancer Res. 2012;72(9):2162-71.

3. Sasada T, Kimura M, Yoshida Y, Kanai M, Takabayashi A. CD4+CD25+ regulatory $T$ cells in patients with gastrointestinal malignancies: possible involvement of regulatory T cells in disease progression. Cancer. 2003;98(5): 1089-99.

4. Viguier M, Lemaître F, Verola O, Cho M-S, Gorochov G, Dubertret L, Bachelez $H$, Kourilsky P, Ferradini L. Foxp3 expressing CD4+CD25(high) regulatory T cells are overrepresented in human metastatic melanoma lymph nodes and inhibit the function of infiltrating T cells. J Immunol. 2004;173(2):1444-53.

5. Bates GJ, Fox SB, Han C, Leek RD, Garcia JF, Harris AL, Banham AH. Quantification of regulatory $T$ cells enables the identification of high-risk breast cancer patients and those at risk of late relapse. J Clin Oncol. 2006; 24(34):5373-80.

6. Wang Q, Xiang Q, Yu L, Hu T, Chen Y, Wang J, Nie X, Cheng J. Changes in tumor-infiltrating lymphocytes and vascular normalization in breast cancer patients after neoadjuvant chemotherapy and their correlations with DFS. Front Oncol. 2020;9:1545.

7. Braga WMT, da Silva BR, de Carvalho AC, Maekawa YH, Bortoluzzo AB, Rizzatti EG, Atanackovic D, Colleoni GWB. FOXP3 and CTLA4 overexpression in multiple myeloma bone marrow as a sign of accumulation of CD4(+) T regulatory cells. Cancer Immunol Immunother. 2014;63(11):1189-97.

8. Idris S-Z, Hassan N, Lee L-J, Md Noor S, Osman R, Abdul-Jalil M, Nordin A-J, Abdullah M. Increased regulatory T cells in acute lymphoblastic leukaemia patients. Hematology. 2016;21(4):206-12.

9. Cader FZ, Schackmann RCJ, Hu X, Wienand K, Redd R, Chapuy B, Ouyang J, Paul N, Gjini E, Lipschitz M, et al. Mass cytometry of Hodgkin lymphoma reveals a CD4(+) regulatory T-cell-rich and exhausted T-effector microenvironment. Blood. 2018;132(8):825-36.

10. Beyer M, Schultze JL. Regulatory T cells in cancer. Blood. 2006:108(3):804-11.

11. Cheng H, Luo G, Jin K, Fan Z, Huang Q, Gong Y, Xu J, Yu X, Liu C. Kras mutation correlating with circulating regulatory $T$ cells predicts the prognosis of advanced pancreatic cancer patients. Cancer Med. 2020. https://doi.org/10.1002/cam1004.2895.

12. Liu Y, Bewersdorf JP, Stahl M, Zeidan AM. Immunotherapy in acute myeloid leukemia and myelodysplastic syndromes: the dawn of a new era? Blood Rev. 2019:34:67-83.

13. Wang HY, Lee DA, Peng G, Guo Z, Li Y, Kiniwa Y, Shevach EM, Wang RF. Tumor-specific human CD4+ regulatory $T$ cells and their ligands: implications for immunotherapy. Immunity. 2004;20(1):107-18.

14. Zou L, Barnett B, Safah H, Larussa VF, Evdemon-Hogan M, Mottram P, Wei S, David O, Curiel TJ, Zou W. Bone marrow is a reservoir for CD4+CD25+ regulatory $T$ cells that traffic through CXCL12/CXCR4 signals. Cancer Res. 2004;64(22):8451-5.

15. Righi E, Kashiwagi $S, Y$ Yuan J, Santosuosso M, Leblanc $P$, Ingraham R, Forbes B, Edelblute B, Collette B, Xing D, et al. CXCL12/CXCR4 blockade induces multimodal antitumor effects that prolong survival in an immunocompetent mouse model of ovarian cancer. Cancer Res. 2011; 71(16):5522-34.

16. Rosser EC, Mauri C. Regulatory B cells: origin, phenotype, and function. Immunity. 2015;42(4):607-12.

17. Olkhanud PB, Damdinsuren B, Bodogai M, Gress RE, Sen R, Wejksza K, Malchinkhuu E, Wersto RP, Biragyn A. Tumor-evoked regulatory B cells promote breast cancer metastasis by converting resting $\mathrm{CD}^{+} \mathrm{T}$ cells to $\mathrm{T}$ regulatory cells. Cancer Res. 2011;71(10):3505-15.

18. Sather BD, Treuting P, Perdue N, Miazgowicz M, Fontenot JD, Rudensky AY, Campbell DJ. Altering the distribution of Foxp3(+) regulatory $T$ cells results in tissue-specific inflammatory disease. J Exp Med. 2007;204(6):1335-47.

19. Burns JM, Summers BC, Wang Y, Melikian A, Berahovich R, Miao Z, Penfold MET, Sunshine MJ, Littman DR, Kuo CJ, et al. A novel chemokine receptor for SDF-1 and I-TAC involved in cell survival, cell adhesion, and tumor development. J Exp Med. 2006;203(9):2201-13.

20. Bach EA, Aguet M, Schreiber RD. The IFN gamma receptor: a paradigm for cytokine receptor signaling. Annu Rev Immunol. 1997;15:563-91.

21. Arber DA, Orazi A, Hasserjian R, Thiele J, Borowitz MJ, Le Beau MM, Bloomfield CD, Cazzola M, Vardiman JW. The 2016 revision to the World Health Organization classification of myeloid neoplasms and acute leukemia. Blood. 2016;127(20):2391-405.

22. Onizuka S, Tawara I, Shimizu J, Sakaguchi S, Fujita T, Nakayama E. Tumor rejection by in vivo administration of anti-CD25 (interleukin-2 receptor alpha) monoclonal antibody. Cancer Res. 1999;59(13):3128-33.

23. Sutmuller RP, van Duivenvoorde LM, van Elsas A, Schumacher TN, Wildenberg ME, Allison JP, Toes RE, Offringa R, Melief CJ. Synergism of cytotoxic T lymphocyte-associated antigen 4 blockade and depletion of CD25(+) regulatory $T$ cells in antitumor therapy reveals alternative pathways for suppression of autoreactive cytotoxic T lymphocyte responses. J Exp Med. 2001;194(6):823-32.

24. Jones E, Dahm-Vicker M, Simon AK, Green A, Powrie F, Cerundolo V, Gallimore A. Depletion of CD25+ regulatory cells results in suppression of melanoma growth and induction of autoreactivity in mice. Cancer Immun. 2002;2:1-1.

25. Szczepanski MJ, Szajnik M, Czystowska M, Mandapathil M, Strauss L, Welsh A, Foon KA, Whiteside TL, Boyiadzis M. Increased frequency and suppression by regulatory $T$ cells in patients with acute myelogenous leukemia. Clin Cancer Res. 2009:15(10):3325-32.

26. Shenghui Z, Yixiang $H$, Jianbo W, Kang Y, Laixi B, Yan Z, Xi X. Elevated frequencies of $\mathrm{CD}^{+} \mathrm{CD} 25^{+} \mathrm{CD} 127$ lo regulatory $T$ cells is associated to poor prognosis in patients with acute myeloid leukemia. Int J Cancer. 2011;129(6): 1373-81.

27. Liu W, Putnam AL, Xu-Yu Z, Szot GL, Lee MR, Zhu S, Gottlieb PA, Kapranov $P$, Gingeras TR, Fazekas de St Groth B, et al. CD127 expression inversely correlates with FoxP3 and suppressive function of human CD4+ T reg cells. J Exp Med. 2006;203(7):1701-11.

28. Sakaguchi S, Wing K, Onishi Y, Prieto-Martin P, Yamaguchi T. Regulatory T cells: how do they suppress immune responses? Int Immunol. 2009;21(10): 1105-11.

29. Randolph DA, Fathman CG. Cd4+Cd25+ regulatory T cells and their therapeutic potential. Annu Rev Med. 2006;57:381-402.

30. Syed Khaja AS, Toor SM, El Salhat H, Ali BR, Elkord E. Intratumoral FoxP3(+ )Helios(+) regulatory $T$ cells upregulating immunosuppressive molecules are expanded in human colorectal cancer. Front Immunol. 2017;8:619.

31. Syed Khaja AS, Toor SM, El Salhat H, Faour I, UI Haq N, Ali BR, Elkord E. Preferential accumulation of regulatory $T$ cells with highly immunosuppressive characteristics in breast tumor microenvironment. Oncotarget. 2017;8(20):33159-71.

32. Langhans B, Nischalke HD, Krämer B, Dold L, Lutz P, Mohr R, Vogt A, Toma $M$, Eis-Hübinger AM, Nattermann J, et al. Role of regulatory $T$ cells and checkpoint inhibition in hepatocellular carcinoma. Cancer Immunol Immunother. 2019;68(12):2055-66.

33. Koehler $\mathrm{H}$, Kofler $\mathrm{D}$, Hombach A, Abken H. CD28 costimulation overcomes transforming growth factor-beta-mediated repression of proliferation of redirected human CD4+ and CD8+ T cells in an antitumor cell attack. Cancer Res. 2007:67(5):2265-73.

34. Mizoguchi A, Mizoguchi E, Takedatsu H, Blumberg RS, Bhan AK. Chronic intestinal inflammatory condition generates $\mathrm{IL}$-10-producing regulatory $\mathrm{B}$ cell subset characterized by CD1d upregulation. Immunity. 2002;16(2):219-30.

35. Lee JH, Noh J, Noh G, Choi WS, Cho S, Lee SS. Allergen-specific transforming growth factor-beta-producing CD19+CD5+ regulatory B-cell $(\mathrm{Br} 3)$ responses in human late eczematous allergic reactions to cow's milk. J Interferon Cytokine Res. 2011;31(5):441-9.

36. Kessel A, Haj T, Peri R, Snir A, Melamed D, Sabo E, Toubi E. Human CD19(+ CD25(high) B regulatory cells suppress proliferation of CD4(+) T cells and enhance Foxp3 and CTLA-4 expression in T-regulatory cells. Autoimmun Rev. 2012;11(9):670-7. 
37. Ray A, Basu S, Williams CB, Salzman NH, Dittel BN. A novel IL-10independent regulatory role for $B$ cells in suppressing autoimmunity by maintenance of regulatory T cells via GITR ligand. J Immunol (Baltimore, Md: 1950). 2012:188(7):3188-98

38. Amu S, Saunders SP, Kronenberg M, Mangan NE, Atzberger A, Fallon PG Regulatory B cells prevent and reverse allergic airway inflammation via FoxP3-positive T regulatory cells in a murine model. J Allergy Clin Immunol. 2010;125(5):1114-1124.e1118.

39. Chen T, Song D, Min Z, Wang X, Gu Y, Wei B, Yao J, Chen K, Jiang Z, Xie H, et al. Perioperative dynamic alterations in peripheral regulatory $T$ and $B$ cells in patients with hepatocellular carcinoma. J Transl Med. 2012;10:14.

40. Guan H, Wan Y, Lan J, Wang Q, Wang Z, Li Y, Zheng J, Zhang X, Wang Z, Shen $Y$, et al. PD-L1 is a critical mediator of regulatory B cells and T cells in invasive breast cancer. Sci Rep. 2016;6:35651.

\section{Publisher's Note}

Springer Nature remains neutral with regard to jurisdictional claims in published maps and institutional affiliations.

Ready to submit your research? Choose BMC and benefit from:

- fast, convenient online submission

- thorough peer review by experienced researchers in your field

- rapid publication on acceptance

- support for research data, including large and complex data types

- gold Open Access which fosters wider collaboration and increased citations

- maximum visibility for your research: over $100 \mathrm{M}$ website views per year

At BMC, research is always in progress.

Learn more biomedcentral.com/submissions 